\title{
Genetic Virulence Determinants and Antimicrobial Susceptibility Profile of Escherichia coli Isolated from Some Milk Products
}

\section{Hala S.H. Salam ${ }^{1}$, Asmaa El-Sayed Zaghloul ${ }^{2}$, Esraa G. Hefny ${ }^{3}$, Essam I. Eltoukhy ${ }^{4}$, AbdelHafez Samir ${ }^{5}$,Abeer A.E. Shehata ${ }^{6 *}$}

${ }^{1}$ Department of Bacteriology, Mycology and Immunology, Faculty of Veterinary Medicine, Beni-Suef University, Beni-Suef, Egypt; ${ }^{2}$ Directorate of Veterinary Medicine, El-Fayoum, Egypt. ${ }^{3}$ Food Hygiene Department, Animal Health Research Institute, ARC Research Institute, Egypt; ${ }^{4}$ Biotechnology Department, Animal Health Research Institute, ARC, Egypt; ${ }^{5} \mathrm{NLQP}$, Animal Health, ARC, Egypt; ${ }^{6}$ Department of Bacteriology, Animal Health Research Institute, El-Fayoum Laboratory, El-Fayoum, Agricultural Research Center, Egypt.

\begin{abstract}
Escherichia (E.) coli is a highly versatile bacterial species habitats intestinal tract of warm-blooded animals as a normal flora and it can cause severe illnesses in different animal species and human being. Dairy products are considered a source of $E$. coli to humans. In humans, it could cause variety of diseases ranges from bloody diarrhea to hemolytic uremic syndrome. This study aimed at studying the prevalence of $E$. coli in yoghurt, kariesh cheese and cream, inspecting the prevalent $E$. coli serogroups, investigating their antimicrobial susceptibility profile using the disk diffusion test and determining some of its virulence genes. A total of 155 samples were collected (50, 50 and 55 from yoghurt, cream and kariesh cheese, respectively) from local markets in El-Fayoum Governorate, Egypt. The prevalence of $E$. coli in yoghurt, cream and kariesh cheese were 12.0, 56.0 and 61.8\%, respectively. There were 11 different serogroups of E. coli amongst the inspected isolates. Serogroups O: 55, O: 114 and O: 125 were identified in the whole examined products, while serogroups O: 26, O: 27 and O: 78 were identified in yoghurt and kariesh cheese only. Antimicrobial resistance against ampicillin, streptomycin, trimethoprim-sulfamethoxazole, cefotaxime, nalidixic acid, tetracycline, and amoxicillin-clavulanic acid were $11.8,10.3,8.8,7.4,5.9,4.4$, and 4.4\%, respectively. Moreover, multidrug resistance was noted in $10.3 \%$ of the inspected $E$. coli isolates. PCR revealed the presence of ast $\mathrm{A}$, eaeA, st $x 1$ and st $x 2$ genes in 100, 50, 20 and 10\%, respectively of the tested isolates. The present study clarify that yoghurt, kariesh cheese and cream to be potential sources of various $E$. coli pathotypes harboring virulence factors able to induce lethal diseases in humans. Moreover, multidrug resistant strains of $E$. coli that even if non-pathogenic will participate in establishing resistance in gastrointestinal tract bacterial community and subsequently environment. So, there is a fundamental need to follow the implementation of both good hygiene and manufacturing practices as well as application of strict hazards analysis and critical control point in dairy products industry for the sake of human safety.
\end{abstract}

Keywords | E. coli, Virulence, Genes, Serogroupe, Cheese

Received | May 21, 2021; Accepted | July 05, 2021; Published | November 01, 2021

*Correspondence | Abeer Ahmed El-Sayed Shehata, Department of Bacteriology, Animal Health Research Institute, El-Fayoum Laboratory, El-Fayoum, Agricultural Research Center, Egypt; Email: aae_shehata@yahoo.com

Citation | Salam HSH, Zaghloul AE-S, Hefny EG, Eltoukhy EI, Samir A, Shehata AAE (2021). Genetic virulence determinants and antimicrobial susceptibility profile of Escherichia coli isolated from some milk products. Adv. Anim. Vet. Sci. 9(12): 2139-2146.

DOI | http://dx.doi.org/10.17582/journal.aavs/2021/9.12.2139.2146

ISSN (Online) | 2307-8316; ISSN (Print) | 2309-3331

Copyright $(92021$ Salam et al. This is an open access article distributed under the Creative Commons Attribution License, which permits unrestricted use, distribution, and reproduction in any medium, provided the original work is properly cited.

\section{INTRODUCTION}

$E$ cherichia coli (E. coli) is Gram-negative bacilli belongs to the family Enterobacteriaceae. E. coli strains habitat intestinal tract (Lara et al., 2016) of both animal and humans normally as a non-pathogenic bacilli. Although most of $E$. coli strains are non-pathogenic, some strains are well armed with a variety of virulence factors that are 
diverge in accordance to the pathotype of $E$. coli.

Pathogenic E. coli have been classified into two categories; the diarrheagenic E. coli (DEC) and the extraintestinal pathogenic E. coli (ExPEC). Among the diarrheagenic $E$. coli, there are currently six categories including enteropathogenic $E$. coli (EPEC), enterotoxigenic $E$. coli (ETEC), enteroinvasive $E$. coli (EIEC), enteroaggregative $E$. coli (EAEC), diffusively adherent $E$. coli (DAEC) and enterohemorrhagic E. coli (EHEC)/Shiga toxin-producing E. coli (STEC) (Xiaodong, 2010). While extra-intestinal pathogenic E. coli (ExPEC) can be classified into three categories, namely, uropathogenic E. coli (UPEC) causing urinary tract infection (UTI), meningitis-associated $E$. coli (MNEC) and necrotoxigenic E. coli (NTEC) which produces cytotoxic necrotizing factor (CNF) (Kaper et al., 2004).

Milk and milk products including (yoghurt, kariesh cheese and cream) are consumed worldwide. They classified as sources of great biological value protein, principal vitamins and minerals (Pereira, 2014). Consumption of raw milk and raw-milk products are widely distributed in several countries as well as Egypt (Ayad et al., 2004). On the other hand, they are considered as source of possibly injurious bacteria to humans, such as pathogenic $E$. coli (Oliver et al., 2005). E. coli can gain access to milk via fecal contamination or via direct secretion (mastitis) from udder into milk (Stephan and Kühn, 1999).

STEC represent a dangerous public health problem worldwide initiating several human gastrointestinal tract diseases, including watery or bloody diarrhea, and may lead to a life-threatening disease, such as haemorrhagic colitis (HC), thrombotic thrombocytopenic purpura (TTP) and hemolytic uremic syndrome (HUS) (Kalid and Andreoli, 2018). STEC strains yield two powerful cytotoxins initiating tissue damage in humans called Shiga toxins or verotoxins (stx1/vt1 and $s t x 2 / v t 2$ ) (Li et al., 2017). Stx2 producing strains are frequently linked to more severe infections (Muniesa et al., 2004).

Other virulence factor likewise, outer membrane protein intimin that is encoded by the eaeA gene and firmly attach and form attaching and effacing lesions to intestinal epithelial cells (Awad et al., 2020). Another dangerous aspect of pathogenic $E$. coli is the presence of the ast $\mathrm{A}$ gene encoding enteroaggregative heat-stable enterotoxin 1 (EAST1) which was primarily distinguished in EAEC (Dubreuil, 2017). Afterward, ast A gene was detected in another DEC pathotypes including EPEC, ETEC, and EHEC (Ménard and Dubreuil, 2002). The ast A gene possibly is a significant virulence factor in DEC which could be injurious to humans (Hinenoya et al., 2014).
The present study aimed at investigating some dairy products (yoghurt, kariesh cheese and cream) manufactured and retailed under market situations for the prevalence of $E$. coli, prevalent serogroups, presence of some virulence genes. Additionally, to study their antimicrobial susceptibility profile against antimicrobial agents of veterinary and humans medicine concern.

\section{MATERIALS AND METHODS}

\section{Samples}

A total of 155 samples from different milk byproducts ( 50 yoghurt, 55 kariesh cheese and 50 cream samples) were collected from different supermarkets, retail and dairy shops in Al-Fayoum governorate, Egypt during the period from August 2019 to February 2020. Samples were transferred in sterile containers to the laboratory and analyzed directly on arrival for the isolation of E. coli.

\section{ISOLATION AND IDENTIFICATION OF $\boldsymbol{E}$. COLI}

Isolation and biochemical identification of $E$. coli was done according to Collee et al. (1996).

\section{Detection OF HEMOLYTIC ACTIVITY OF THE}

\section{IDENTIFIED $E$. COLI ISOLATES}

The ability of $E$. coli isolates to produce different types of hemolysin was phenotypically investigated using sheep blood agar 7\% (Collee et al., 1996).

\section{SEROGROUPING OF THE ISOLATED $E$. COLI}

Serogrouping of $E$. coli isolates recovered from different milk byproducts was performed in accordance to Ewing (1986). I was performed in Department of Serology, Animal Health Research Institute, Agricultural Research Center, Egypt.

\section{IN VITRO ANTIMICROBIAL SUSCEPTIBILITY TESTING OF THE IDENTIFIED $E$. COLI STRAINS}

The isolated $E$. coli strains were investigated for their antimicrobial susceptibility profile using disk diffusion test against different antimicrobial classes of veterinary and human being significance. Second generation cephalosporin (cefoxitin, 30 $\mu \mathrm{g}$ ); third generation cephalosporin (cefotaxime, $30 \mu \mathrm{g}$ ); penicillin-inhibitor combination (amoxicillin-clavulanic acid, $30 \mu \mathrm{g}$ ); aminoglycosides (gentamicin, $10 \mu \mathrm{g}$ and streptomycin, $10 \mu \mathrm{g}$ ); tetracyclines (tetracycline $10 \mu \mathrm{g}$ ); quinolone (nalidixic acid $30 \mu \mathrm{g}$ ); fluoroquinolone (ciprofloxacin, 5 $\mu \mathrm{g})$; carbapenem (imipenem, $10 \mu \mathrm{g}$ ); and folate pathway antagonist (trimethoprim-sulfamethoxazole, $25 \mu \mathrm{g}$ ). All antimicrobial disks were obtained from Oxoid, UK. The in vitro antimicrobial susceptibility profiling and results interpretation were performed according to CLSI (2019). 
Table 1: Oligonucleotide primer sequences of target genes specific for $E$. coli.

$\begin{array}{llll}\text { Gene } & \text { Primer sequence (5'-3') } & \text { Amplicon size } & \text { Reference } \\ \text { stx1 } & \text { ACACTGGATGATCTCAGTGG } & 614 \mathrm{bp} & \text { Dipineto et al. (2006) } \\ & \text { CTGAATCCCCCTCCATTATG } & & \\ \text { stx2 } & \text { CCATGACAACGGACAGCAGTT } & 779 \mathrm{bp} & \\ & \text { CCTGTCAACTGAGCAGCACTTTG } & & \\ \text { eaeA } & \text { ATGCTTAGTGCTGGTTTAGG } & 248 \mathrm{bp} & \text { Bisi-Johnson et al. (2011) } \\ & \text { GCCTTCATCATTTCGCTTTC } & & \\ \text { ast } A & \text { CCATCAACACAGTATATCCGA } & 110 \mathrm{bp} & \text { Piva et al. (2003) } \\ & \text { GGTCGCGAGTGACGGCTTTGT } & & \end{array}$

Table 2: PCR cycling conditions of the different primer sets.

\begin{tabular}{|lllllll}
\hline Gene & $\begin{array}{l}\text { Primary } \\
\text { denaturation }\end{array}$ & $\begin{array}{l}\text { Secondary } \\
\text { denaturation }\end{array}$ & Annealing & Extension & $\begin{array}{l}\text { No. of } \\
\text { cycles }\end{array}$ & Final extension \\
\hline stx 1 and stx 2 & $94^{\circ} \mathrm{C} 5 \mathrm{~min}$. & $94^{\circ} \mathrm{C} 30 \mathrm{sec}$. & $58^{\circ} \mathrm{C} 40 \mathrm{sec}$. & $72^{\circ} \mathrm{C} 45 \mathrm{sec}$. & 35 & $72^{\circ} \mathrm{C} 10 \mathrm{~min}$. \\
\hline eaeA & $94^{\circ} \mathrm{C} 5 \mathrm{~min}$. & $94^{\circ} \mathrm{C} 30 \mathrm{sec}$. & $51^{\circ} \mathrm{C} 30 \mathrm{sec}$. & $72^{\circ} \mathrm{C} 30 \mathrm{sec}$. & 35 & $72^{\circ} \mathrm{C} 7 \mathrm{~min}$. \\
\hline ast $A$ & $94^{\circ} \mathrm{C} 5 \mathrm{~min}$. & $94^{\circ} \mathrm{C} 30 \mathrm{sec}$. & $55^{\circ} \mathrm{C} 30 \mathrm{sec}$. & $72^{\circ} \mathrm{C} 30 \mathrm{sec}$. & 35 & $72^{\circ} \mathrm{C} 7 \mathrm{~min}$. \\
\hline
\end{tabular}

DETECTION OF SOME VIRULENCE GENES IN THE PREVALENT E. COLI SEROGROUPS ISOLATED FROM DAIRY PRODUCTS USING POLYMERASE CHAIN REACTION (PCR)

Presence of ast $\mathrm{A}$, eae $\mathrm{A}$, st $x 1$, and $s t x 2$ in the most prevalent serogroups of the isolated $E$. coli was done using PCR .

\section{Preparation of DNA template}

DNA template was obtained from overnight pure culture using QIAamp DNA Mini Kit (Catalogue no.51304) from Qiagen.

\section{AMPLIFICATION PROCEDURE}

PCR reactions were performed in volumes of $25 \mu \mathrm{L}$. Primers were obtained from Metabion (Germany) and master mix from Takara (Catalogue no. RR310). Table 1 reveals the used primer pairs for each gene, amplicon size and references used and Table 2 shows the cycling condition for each primer pairs. Ten microliters of the reaction products were analyzed by electrophoresis on $1 \%$ agarose gel containing ethidium bromide and results were visualized in a gel documentation system.

\section{Statistical ANALYSiS}

ANOVA test was used to investigate the prevalence of $E$. coli in different dairy products. Statistical significance was considered if $p \leq 0.05$. All statistical comparisons were performed using IBM SPSS ${ }^{\circledast}$ Statistics software version 22.

\section{RESULTS AND DISCUSSION}

Prevalence of $\boldsymbol{E}$. COLI IN DifFERENT DAIRY PRODUCTS E. coli prevalence (Table 3 ) differed according to the niche of dairy products. The highest prevalence $(61.8 \%)$ was noted in kariesh cheese followed cream (56\%), while the least prevalence was reported amongst yoghurt samples (12\%). The overall prevalence of $E$. coli in the examined samples of the dairy products was $43.9 \%$.

Table 3: Prevalence of $E$. coli isolated from dairy products.

\begin{tabular}{|c|c|c|c|}
\hline \multirow[t]{2}{*}{ Dairy product } & \multirow[t]{2}{*}{ Samples No. } & \multicolumn{2}{|c|}{ E. coli } \\
\hline & & No. & $\%^{*}$ \\
\hline Yoghurt & 50 & 6 & $12.0^{\S}$ \\
\hline Kariesh cheese & 55 & 34 & 61.8 \\
\hline Cream & 50 & 28 & 56.0 \\
\hline $\begin{array}{l}\text { Total number } \\
* \% \text { : Percentage } \\
\text { number of exami } \\
\text { was statistically } 1 \\
\text { cream }(p<0.05) \text {. }\end{array}$ & $\begin{array}{l}155 \\
\text { lated according } \\
\text { les; §: Prevalenc } \\
\text { those reported }\end{array}$ & & $\begin{array}{l}43.9 \\
\text { respond } \\
\text { in yog1 }\end{array}$ \\
\hline
\end{tabular}

Prevalence of $E$. coli in yoghurt was statistically lower than those reported in kariesh cheese and cream $(p<0.05)$. In contrast, kariesh cheese and cream $E$. coli prevalence difference was not statistically different $(p>0.05)$.

\section{HeMOLYTIC ACTIVITY OF $\boldsymbol{E}$. COLI ISOLATES}

Alpha hemolysis was the only type of hemolysis phenotypically detected in $E$. coli isolated in the present study. Alpha-hemolytic activity was reported in 16 (23.5\%) out of the inspected 68 isolates (one isolate recovered from cream and 15 isolates from kariesh cheese), while the remaining isolates were non-hemolytic i.e. gammahemolytic.

\section{SEROGROUPING OF $\boldsymbol{E}$. COLI ISOLATES}

Table 4 reveals the presence of 11 serogroups of E. coli amongst investigated 20 isolates that were selected to 
represent the examined dairy products (yoghurt, 5; kariesh cheese, 7 and cream, 8) under study (Table 4). Serogroups O55, O114 and 125 were reported in the investigated three dairy products.

Table 4: Serogrouping of $E$. coli isolates recovered from dairy products.

\begin{tabular}{|c|c|c|}
\hline Product & No. of isolates & Serogroup \\
\hline \multirow[t]{5}{*}{ Yoghurt } & \multirow[t]{5}{*}{5} & $\mathrm{O} 25$ \\
\hline & & O55 \\
\hline & & O114 \\
\hline & & O125 \\
\hline & & O128 \\
\hline \multirow[t]{7}{*}{ Kariesh cheese } & \multirow[t]{7}{*}{7} & $\mathrm{O} 26$ \\
\hline & & $\mathrm{O} 27$ \\
\hline & & O55 \\
\hline & & O78 \\
\hline & & O114 \\
\hline & & O124 \\
\hline & & O125 \\
\hline \multirow[t]{8}{*}{ Cream } & \multirow[t]{8}{*}{8} & $\mathrm{O} 26$ \\
\hline & & $\mathrm{O} 27$ \\
\hline & & O55 \\
\hline & & $\mathrm{O} 78$ \\
\hline & & O86 \\
\hline & & O114 \\
\hline & & O125 \\
\hline & & O148 \\
\hline
\end{tabular}

ANTIMicrobial SUSCEPTIBILITY TESTING OF $\boldsymbol{E}$. COLI RECOVERED FROM DAIRY PRODUCTS

The in vitro antimicrobial susceptibility testing revealed diverse susceptibility/resistance behavior of the investigated $E$. coli against the tested antimicrobial agents (Table 5). All 68 tested isolates were 100\% sensitive to gentamicin, imipenem, and cefoxitin. On the other hand, the resistance rates against ampicillin, streptomycin, trimethoprimsulfamethoxazole, cefotaxime, nalidixic acid, tetracycline and amoxicillin-clavulanic acid were 11.8, 10.3, 8.8, 7.4, 5.9, 4.4 and 4.4\%, respectively. Additionally, multidrug resistance was noted in seven out of $68(10.3 \%)$ of the inspected $E$. coli isolates.

Detection of SOME VIRULENCE GENES IN THE PREVALENCE $E$. COLI SEROGROUPS ISOLATED FROM DAIRY PRODUCTS

The presence of ast $\mathrm{A}$ gene was confirmed in the isolates $(100 \%)$ under test (Figure 1), while eaeA was only defined in five out of ten (50\%) investigated isolates (Figure 2). Regarding to shiga toxins, st 1 and $s t \times 2$ were only defined in one (10\%) and two (20\%) of the tested isolates, respectively
(Figure 3). Results clarify all isolates harboring shiga toxin genes also harbored ast $\mathrm{A}$ and $e a e \mathrm{~A}$ genes.

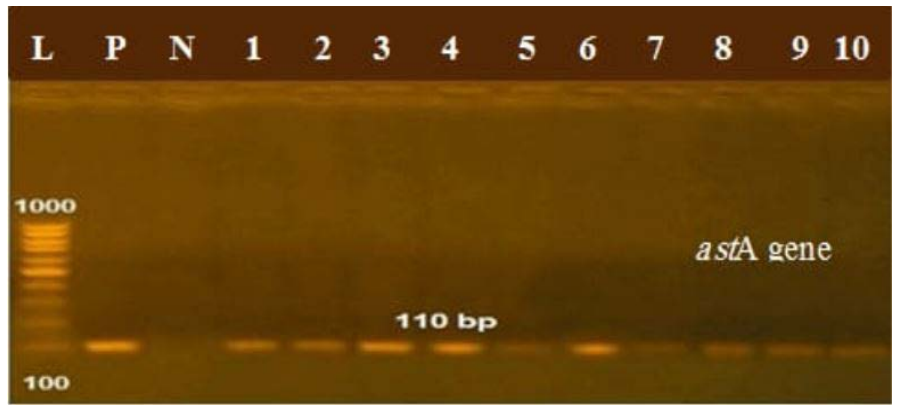

Figure 1: Lanes 1:10 positive amplification of ast $\mathrm{A}$ gene at 110 bp P: positive control; N: negative control; L: DNA ladder.

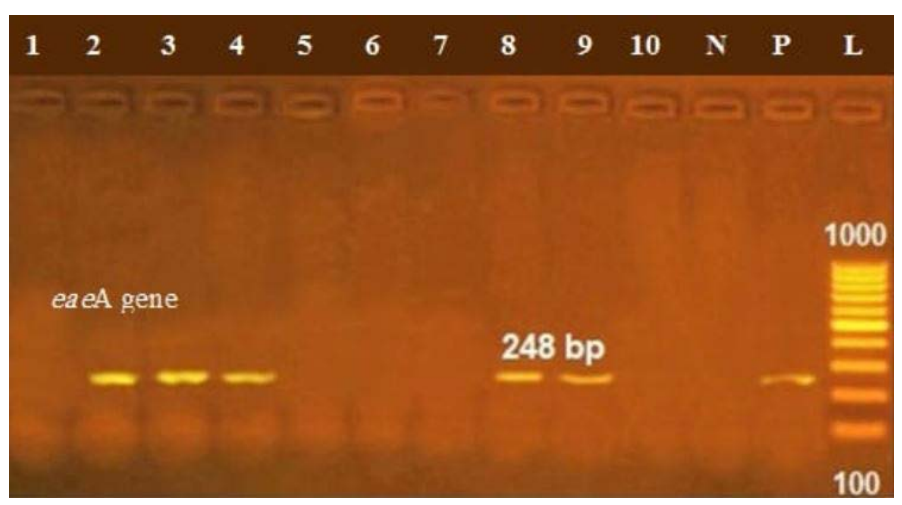

Figure 2: Lanes 2, 3, 7, 8, 9 positive amplification of eaeA gene at 248 bp; P: positive control; N: negative control; L: DNA ladder.

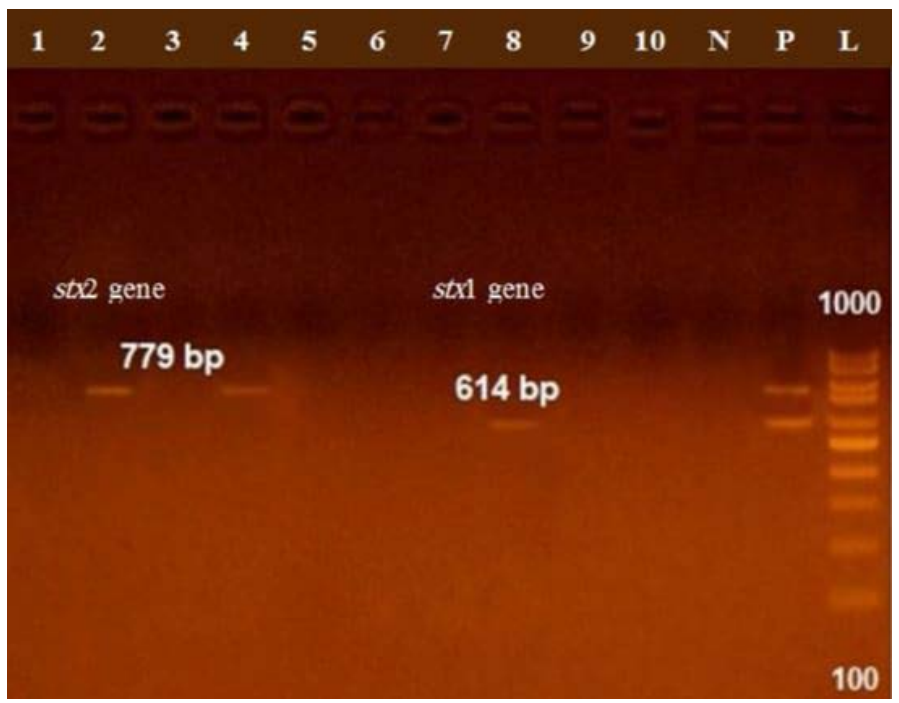

Figure 3: Lane 8 positive amplification of $s t x 1$ gene at 614 bp Lanes 2, 4 positive amplification of stx2 gene at $779 \mathrm{bp}$; P: positive control; N: negative control; L: DNA ladder.

Dairy products like yoghurt, cheese, and cream are widely consumed and markets have existed for them in many parts of the world for many generations. Dairy products over and above they are of high nutritional value for humans, they also offer an apt niche for bacterial growth likewise $E$. coli. 
Table 5: Results of antimicrobial sensitivity test to $68 \mathrm{E}$. coli isolates from dairy products using the disk diffusion method.

\begin{tabular}{|c|c|c|c|c|c|c|c|}
\hline \multirow[t]{2}{*}{ Class } & \multirow[t]{2}{*}{ Antimicrobial agent } & \multicolumn{2}{|c|}{ Sensitive } & \multicolumn{2}{|c|}{ Intermediate } & \multicolumn{2}{|c|}{ Resistant } \\
\hline & & No. & $\%$ & No. & $\%$ & No. & $\%$ \\
\hline Penicillin & Ampicillin & 60 & 88.2 & 0 & 0 & 8 & 11.8 \\
\hline $\begin{array}{l}\text { ß-lactam } / \beta \text {-lactamase inhibitor } \\
\text { combinations }\end{array}$ & Amoxicillin-clavulanic acid & 65 & 95.6 & 0 & 0 & 3 & 4.4 \\
\hline Third generation cephalosporins & Cefotaxime & 63 & 92.6 & 0 & 0 & 5 & 7.4 \\
\hline Second generation cephalosporins & Cefoxitin & 68 & 100 & 0 & 0 & 0 & 0 \\
\hline Carbapenems & Imipenem & 68 & 100 & 0 & 0 & 0 & 0 \\
\hline \multirow[t]{2}{*}{ Aminoglycosides } & Gentamicin & 68 & 100 & 0 & 0 & 0 & 0 \\
\hline & Streptomycin & 54 & 79.4 & 7 & 10.3 & 7 & 10.3 \\
\hline Tetracyclines & Tetracycline & 63 & 92.6 & 2 & 2.9 & 3 & 4.4 \\
\hline \multirow[t]{2}{*}{ Quinolones } & Ciprofloxacin & 66 & 97.1 & 2 & 2.9 & 0 & 0 \\
\hline & Nalidixic acid & 64 & 94.1 & 0 & 0 & 4 & 5.9 \\
\hline Folate pathway antagonist & $\begin{array}{l}\text { Trimethoprim- } \\
\text { sulfamethoxazole }\end{array}$ & 61 & 89.7 & 1 & 1.5 & 6 & 8.8 \\
\hline
\end{tabular}

\%: Percentages were calculated in relation to the total number of tested isolates.

E. coli finds its way to milk and dairy products either, endogenously from the udder of diseased animal and or exogenously via direct contact with infected herds, environment or personnel (Farzana, 2009). In another consequence, E. coli is one of the main indicator organisms used for evaluating the quality of food (Anderson et al., 2006).

The present study revealed a diversity in the prevalence of $E$. coli in the examined dairy products (yoghurt, kariesh cheese and cream) (Table 3). The lowest prevalence was for yoghurt, $12 \%$ (6 isolates out of 50 samples) and it was significantly lower than those reported for kariesh cheese and cream $(p<0.05)$. Low isolation rate of $E$. coli from yoghurt could be explained on the bases of the organic acid and low molecular weight antimicrobial substance produced by fermenting bacteria in yoghurt such as Lactobacillus spp. that showed in vitro antimicrobial activity against $E$. coli (Prabhurajeshwar and Chandrakanth, 2019).

Comparing the results of $E$. coli prevalence in yoghurt in the present study with other scholars' result, identical prevalence of $E$. coli (12\%) was noted by Okpalugo et al. (2008) in Abuja, Nigeria. On the other hand, Chaleshtori et al. (2017) reported closely matching isolation rate of $E$. coli (10\%) from yoghurt in Iran. Higher isolation rates of E. coli form yoghurt were also reported 29.5, 44.8 and 88.0 $\%$ in Osun, Nigeria; El-Behera, Egypt and Mansoura city, Dakahlia Governorate, Egypt, respectively (El-Ansary, 2014; Abike et al.,2015; Kandil et al.,2018). Higher rates of E. coli from yoghurt in different studies could be attributed to the initial load of the milk before processing; usage of mastitic milk (Awadallah et al., 2016), improper sanitation of equipment used during processing; contamination after processing by unhygienic handling, packaging material
(Pal et al., 2018) or to the storage temperature and time elapsed from manufacturer till sampling (Bachrouri et al., 2006).

On the other hand, the prevalences of $E$. coli in kariesh cheese and cream were 61.8 and 56\%, respectively. Higher isolation rates of E. coli from kariesh cheese and cream could be attributed to the preparation of these products from mastitic milk (Awadallah et al., 2016) raw milk with high bacterial count, probiotic bacteria are not used in their preparation and also external contamination could occur at one or more points during processing (Deschenes et al., 1996). Non-statistical significant $(p>0.05)$ of $E$. coli isolation rates from kariesh cheese and cream could be attributed to preparation of cream and kariesh cheese from the same milk source. Additionally, previous studies reported a range of $40-75 \%$ and $37.5-76.7 \%$ isolation rates of $E$. coli from kariesh cheese and cream in different regions in Egypt (Abd E1-Tawab et al., 2020; Baraheem et al., 2007; E1 Nahas et al., 2015; Ibrahim et al., 2019).

Out of 20 E. coli isolates represented the dairy products under study 11 serogroups (Table 4) were identified (O25, O26, O27, O55, O78, O86, O114, O124, O125, O128, O148). El-Bagory et al. (2004) identified verotoxigenic $E$. coli $\mathrm{O} 26$ from the examined yoghurt samples. Also, Abike et al. (2015) found O26, O55, O86, O114, and O128 serogroups in raw milk, yoghurt and cheese. In a previous study, similar E. coli serogroups (O26, O55, and O114) were recovered from kariesh cheese and (O26, O55 and O114) form cream (E1 Nahas et al., 2015). Many scholars (Scott et al., 2009; Osman et al., 2013; Shehata and Salam, 2012; Awadallah et al., 2016) reported different E. coli serogroups either in diarrheic calves, healthy cattle or mastitic milk (O25, O26, O55, O78, 86, O114, O125, O148). 
All isolates of $E$. coli recovered from dairy products in the present study were tested for their susceptibility behavior against 11 antimicrobial agents represented different antimicrobial classes of human being and veterinary concern in the region under study. The in vitro antimicrobial susceptibility testing revealed diverse susceptibility/resistance behavior of the investigated E. coli isolates against the tested antimicrobial agents (Table 5). All 68 tested isolates were 100\% sensitive to gentamicin, imipenem, and cefoxitin. On the other hand, the resistance rates against ampicillin, streptomycin, trimethoprimsulfamethoxazole, cefotaxime, nalidixic acid, tetracycline, and amoxicillin-clavulanic in descending order were 11.8, $10.3,8.8,7.4,5.9,4.4$ and 4.4\%, respectively. Side by side, growing of resistance was observed by the intermediate behavior of the investigated isolates against the tested antimicrobial agents. The percentages of the intermediate zones in ascending order were 1.5, 2.9 and $10.3 \%$ against trimethoprim-sulfamethoxazole, ciprofloxacin and streptomycin in turn. Additionally, multidrug resistance was noted in seven out of 68 (10.3\%) of the inspected $E$. coli isolates.

Results divulged the correlation between the used antimicrobial agents in veterinary medicine and the reporting of resistance in isolates of veterinary origin and vice versa. Cefoxitin, imipenem and ciprofloxacin are of notorious use in medication of large animals and this could explain the results of $0.0 \%$ resistance records against these antimicrobial agents. Although the development of intermediate sensitivity behavior against ciprofloxacin and this could be due to the use of ciprofloxacin in broiler industry (Jónsdóttir and Kristinsson, 2008) that can later finds its way to the environmental niche either to humans or other animals. On the other hand, some antimicrobial classes showed higher rates of either resistance or intermediate behavior against the tested $E$. coli isolates likewise, penicillins, aminoglycosides, and tetracyclines, quinolones (first generation) and sulfonamides as these agents are of wide use in veterinary sectors and listed by the OIE as antimicrobial agents of veterinary importance (OIE, 2019). Furthermore, this could explain the prevalence of multidrug resistance amongst the tested isolates (10.3\%).

Higher prevalence rates of resistance were reported in Mansoura city, Egypt against streptomycin, nalidixic, cefotaxime, tetracycline, trimethoprim-sulfamethoxazole, ampicillin, ciprofloxacin and gentamicin 100, 80, 60, 60, $60,40,40$ and $20 \%$ in descending order (E1-Baz, 2019). Also, Abd El-Tawab et al. (2020) reported 16.7\% resistance amongst the E. coli tested against tetracycline in ElGharbia Governorate, Egypt. There is a direct correlation between the abuse of antimicrobials and emergence of resistance amongst bacterial communities (Aly, 2013) and this could expound the metamorphosis in resistance profile of $E$. coli in different areas.

E. coli tempt its pathogenic actions through versatile sets of virulence elements that work in harmony to produce various illnesses in animals and humans. Phenotypic detection of hemolysis revealed the presence of $\alpha$-hemolysin in $23.5 \%$ of the inspected isolates that is an exotoxin produced by E. coli and enhances virulence in clinical infections (May et al., 2000). Side by side, genotypic investigation revealed the presence of ast $\mathrm{A}, e a e \mathrm{~A}, s t x 1$ and $s t x 2$ genes in variable rates in ten $E$. coli isolates represented those isolated from dairy products under investigation (Figures 1, 2 and 3). All isolated had ast $\mathrm{A}$ gene, eaeA was represented in five isolates while st $x 1$ and st $x 2$ were only noticed in two and one isolates, respectively. EAST1 induced by ast $\mathrm{A}$ gene associates diarrheagenic E. coli in humans and animals and other scholars noted there presence even with nondiarrheagenic E. coli (Hinenoya et al., 2014) isolated from healthy cattle and swine. All shiga toxin genes (either $s t x 1$ or $s t x 2)$ positive isolates were positive also for eaeA gene. This makes dairy products act as a potential source of STEC for humans as eaeA genes induce adhesion protein secretion required for intimate adherence of $E$. coli (Blank et al., 2002) that give chance for the cells of E. coli to produce shiga toxins to induce either watery or bloody diarrhea and may lead to a lethal disease such as HC, TTP and HUS (Khalid and Anderoli, 2018).

Researchers in different regions reported ast $\mathrm{A}$, eae $\mathrm{A}$, st $x 1$ and $s t x 2$ genes in E. coli isolated from dairy products with variable prevalence rates (Elafify et al., 2020; Dehkordi et al., 2014) which could be attributed to the difference in the circulating serotypes in every study area.

\section{CONCLUSIONS AND RECOMMENDATIONS}

The present study points to yoghurt, kariesh cheese and cream as serious potential source of various $E$. coli pathotypes harboring virulence factors able to induce lethal diseases in humans. Moreover, multidrug resistant strains of $E$. coli that even if non-pathogenic will participate in establishing resistance in gastrointestinal tract bacterial community and environment. So, there is a fundamental need to follow the implementation of both good hygiene and manufacturing practices as well as application of strict hazards analysis and critical control point in dairy products industry for the sake of human safety.

\section{AUTHOR'S CONTRIBUTION}

\section{All authors contributed equally.}




\section{CONFLICT OF INTEREST}

The authors have declared no conflict of interest.

\section{REFERENCES}

-Abd E1-Tawab AA, Eid A, Khater D, Weheba MY (2020). The occurrence of pathogenic $E$. coli in some types of soft cheeses in the local market. Benha Vet. Med. J., 39(1): 5-10.

-Abike TO, Olufunke OA, Oriade KD (2015). Prevalence of multiple antibiotic resistant Escherichia coli serotypes in cow raw milk samples and traditional dairy products in Osun State, Nigeria. Br. Microbiol. Res. J., 5(2): 117-125.

-Aly SM (2013). Risk of antimicrobial misuse. Int. J. Health Sci., 7(1): V-VII.

-Anderson MA, Whitlock JE, Harwood VJ (2006). Diversity and distribution of Escherichia coli genotypes and antibiotic resistance phenotypes in feces of humans, cattle, and horses. Appl. Environ. Microbiol., 72(11): 6914-6922.

-Awad WS, El-Sayed AA, Mohammed FF, Bakry NM, Abdou NMI, Kamel MS (2020). Molecular characterization of pathogenic Escherichia coli isolated from diarrheic and incontact cattle and buffalo calves. Trop. Anim. Health Prod., 52(6): 3173-3185.

-Awadallah MA, Ahmed HA, Merwad AM, Selim MA (2016). Occurrence, genotyping, shiga toxin genes and associated risk factors of $E$. coli isolated from dairy farms, handlers and milk consumers. Vet. J., 217: 83-88.

-Ayad EHE, Awad S, El-Attar A, De Jong C, El-Soda M (2004). Characterisation of Egyptian Ras cheese. 2. Flavour formation. Food Chem., 86(4): 553-561.

- Bachrouri M, Quinto EJ, Mora MT (2006). Kinetic parameters of Escherichia coli O157:H7 survival during fermentation of milk and refrigeration of homemade yoghurt. Int. Dairy J., 16(5): 474-481. https://doi.org/10.1016/j. idairyj.2005.06.002

-Baraheem OH, El-Shamy HA, Bakr WM, Gomaa NF (2007). Bacteriological quality of some dairy products (Kariesh cheese and ice cream) in Alexandria. Egypt Publ. Health Assoc., 82(5-6): 491-510.

-Bisi-Johnson MA, Obi CL, Vasaikar SD, Baba KA, Hattori T (2011). Molecular basis of virulence in clinical isolates of Escherichia coli and Salmonella species from a tertiary hospital in the Eastern Cape, South Africa. Gut. Pathog., 3(1): 9.

- Blank TE, Mougayrnuède J, Donnenberg MS (2002). Enteropathogenic Escherichia coli. In Escherichia coli virulence mechanisms of a versatile pathogen, Donnenberg M,(Eds.). Acad. Press, pp. 81-118. https://doi.org/10.1016/ B978-012220751-8/50004-5

- Chaleshtori FS, Arani NM,Aghadavod E, Naseri A, Chaleshtori RS (2017). Molecular characterization of Escherichia coli recovered from traditional milk products in Kashan, Iran. Vet. World, 10(10): 1264. https://doi.org/10.14202/ vetworld.2017.1264-1268

- Clinical and Laboratory Standards Institute (CLSI) (2019). Performance standards for antimicrobial disk susceptibility tests; Approved Standard, Nineteenth Edition.

- Collee JG, Fraser A, Marmion BP, Simmons A (1996). Practical Medical Microbiology. $14^{\text {th }}$ ed. Mackie and McCartney. The English langue book society and Churchill living stone. Edinburgh and New York.

- Dehkordi FS, Yazdani F, Mozafari J, Valizadeh Y (2014). Virulence factors, serogroups and antimicrobial resistance properties of Escherichia coli strains in fermented dairy products. BMC Res. Notes, 7(1): 1-8. https://doi. org/10.1186/1756-0500-7-217

-Deschenes G, Casenave C, Grimont F, Desenclos JC, Benoit S, Collin M, Baron S, Mariani P, Grimont PA, Nivet H (1996). Cluster of cases of haemolytic uraemic syndrome due to unpasteurised cheese. Pediatr. Nephrol., 10(2): 203-205.

-Dipineto L, Santaniello A, Fontanella M, Lagos K, Fioretti A, Menna LF (2006). Presence of Shiga toxin-producing Escherichia coli O157: H7 in living layer hens. Lett. Appl. Microbiol., 43(3): 293-295.

-Dubreuil JD (2017). EAST1 toxin: An enigmatic molecule associated with sporadic episodes of diarrhea in humans and animals. J. Microbiol., 57(7): 541-549.

-El-Nahas AW, Mohamed HA, El-Barbary HA, Mohamed HS (2015). Incidence of $E$. coli in raw milk and its products. Benha Vet. Med.J., 29(1): 112-117.

-Elafify M, Khalifa HO, Al-Ashmawy M, Elsherbini M, ElLatif AA, Okanda T, Matsumoto T, Koseki S, Abdelkhalek A (2020). Prevalence and antimicrobial resistance of Shiga toxin-producing Escherichia coli in milk and dairy products in Egypt. J. Environ. Sci. Health, Part B., 55(3): 265-272.

-El-Ansary MA (2014). Assessment of microbiological quality of yoghurt sold in El-Behera Governorate. Austral J. Vet. Sci., 43(1): 52-57.

-El-Bagory AM, Hammad AM (2004). Prevalence of E. coli O157: H7 and other Verotoxigenic E. coli in raw milk and some dairy products. Alex. J. Vet. Sci., 21(1): 34-40

-El-Baz AH (2019). Prevalence, molecular characterization and antimicrobial resistance of Vero toxigenic $E$. coli in fresh soft cheese, ice cream and yoghurt in Mansoura city. Alex. J. Vet. Sci., 62(1): 38-46.

-Ewing WH (1986). The genus Escherichia. In Edwards and Ewing's Identification of Enterobacteriaceae. New York: Elsevier, pp. 93-134.

- Farzana K, Akhtar S, Jabeen F (2009). Prevalence and antibiotic resistance of bacteria in two ethnic milk-based products. Pak. J. Bot., 41(2): 935-943.

- Hinenoya A, Shima K, Asakura M, Nishimura K, Tsukamoto T, Ooka T, Hayashi T, Ramamurthy T, Faruque SM, Yamasaki S (2014).Molecular characterization of cytolethal distending toxin gene-positive Escherichia coli from healthy cattle and swine in Nara, Japan. BMC Microbiol., 14(1): 1-13.

-Ibrahim E, Elbarbary HA, Shawky NA, El-Sebay I (2019). Incidence and molecular characterization of Escherichia coli in some dairy products. Benha Vet. Med. J., 37(1): 102-106.

- Jónsdóttir K, Kristinsson KG (2008). Quinolone resistance in Gram negative rods in Iceland and association with antibiotic use. Laeknabladid, 94(4): 279-285.

-Kandil AA, Elhadidy M, El-Gamal A, Al-Ashmawy MA (2018). Identification of $S$. aureus and E. coli from dairy products intended for human consumption. Adv. Anim. Vet. Sci., 6(11): 509-513.

-Kaper JB, Nataro JP, Mobley HL (2004). Pathogenic Escherichia coli. Nat. Rev. Microbiol., 2(2): 123-140.

-Khalid M, Anderoli S (2018). Extrarenal manifestations of the hemolytic uremic syndrome associated with Shiga toxinproducing Escherichia coli (STEC HUS). Pediatr. Neprol., 34(12): 2495-2507.

-Lara VM, Carregaro AB, Santurio DF, Sá MFD, Santurio JM, Alves SH (2016). Antimicrobial susceptibility of Escherichia coli strains isolated from Alouatta spp. feces to essential oils. Evid. Based Complement. Altern. Med., (2016): 1-4. 
https://doi.org/10.1155/2016/1643762

- Li B, Liu H and Wang W (2017). Multiplex real-time PCR assay for detection of Escherichia coli O157:H7 and screening for non-O157 Shiga toxin-producing E. coli. BMC Microbiol., 9; 17(1): 215.

- May AK, Gleason TG, Sawyer RG, Pruett TL (2000). Contribution of Escherichia coli alpha-hemolysin to bacterial virulence and to intrapreritoneal alterations in peritonitis. Infect. Immun., 68(1): 176-183.

- Ménard LP, Dubreuil JD (2002). Enteroaggregative Escherichia coli heat-stable enterotoxin 1 (EAST1): a new toxin with an old twist. Crit. Rev. Microbiol., 28(1): 43-60.

- Muniesa M, Blanco JE, De Simón M, Serra-Moreno R, Blanch AR, Jofre J (2004). Diversity of stx2 converting bacteriophages induced from Shiga-toxin-producing Escherichia coli strains isolated from cattle. Microbiology, 150(9): 2959-2971. https://doi.org/10.1099/mic.0.27188-0

- OIE (2019). OIE list of antimicrobial agents of veterinary importance.

- Okpalugo J, Ibrahim K, Izebe KS, Inyang US (2008). Aspects of microbial quality of some milk products in Abuja Nigeria. Trop. J. Pharma. Res., 7(4): 1169-1177.

- Oliver SP, Jayarao BM, Almeida RA (2005). Foodborne pathogens in milk and the dairy farm environment: food safety and public health implications. Foodborne Pathog. Dis., 2(2):115-129. https://doi.org/10.1089/fpd.2005.2.115

- Osman KM, Mustafa AM, Elhariri M, Abdelhamed GS (2013). The distribution of Escherichia coli serovars, virulence genes, gene association and combinations and virulence genes encoding serotypes in pathogenic $E$. coli recovered from diarrhoeic calves, sheep and goat. Transbound. Emerg. Dis., 60(1): 69-78.

-Pal M, Devrani M, Pintoo S (2018). Significance of hygienic processing of milk and dairy products. Madridge J. Food Tech., 3(2): 133-137.

- Pereira PC (2014). Milk nutritional composition and its role in human health. Nutrition, 30 (6): 619-627.

-Piva IC, Pereira AL, Ferraz LR, Silva RS, Vieira AC, Blanco JE, Blanco M, Blanco J, Giugliano LG (2003). Virulence markers of enteroaggregative Escherichia coli isolated from children and adults with diarrhea in Brasilia, Brazil. J. Clin. Microbiol., 41(5): 1827-1832.

- Prabhurajeshwar C, Chandrakanth K (2019). Evaluation of antimicrobial properties and their substances against pathogenic bacteria in-vitro by probiotic Lactobacilli strains isolated from commercial yoghurt. Clin. Nutr. Exp., 23: 97115 .

-Scott L, McGee P, Walsh C, Fanning S, Sweeney T, Blanco J, Karczmarczyk M, Earley B, Leonard N, Sheridan JJ (2009). Detection of numerous verotoxigenic $E$. coli serotypes, with multiple antibiotic resistance from cattle faeces and soil. Vet. Microbiol., 134(3-4): 288-293.

-Shehata AA, Salam HS (2012). Phenotypic characterization of $E$. coli isolated from farm animals with diarrhea: use of lectin as a non-specific immunostimulant. Int. J. Microbiol. Res., 3(3): 227-237.

-Stephan R, Kühn K (1999). Prevalence of verotoxin-producing Escherichia coli (VTEC) in bovine coli mastitis and their antibiotic resistance patterns. Zentralbl Vet. B., 46(6): 423427.

-Xiaodong X (2010). Pathogenic Escherichia coli in retail meats (Doctoral dissertation, Dissertation submitted to the Faculty of the Graduate School of the University of Maryland, College Park, in partial fulfillment of the requirements for the degree of Doctor of Philosophy). 